\title{
PENETAPAN TINDAK PIDANA SEBAGAI KEJAHATAN DAN PELANGGARAN DALAM UNDANG-UNDANG PIDANA KHUSUS*
}

\author{
Supriyadi $^{* *}$ \\ Bagian Hukum Pidana, Fakultas Hukum Universitas Gadjah Mada, Yogyakarta \\ Jalan Sosio Yustisia Nomor 1 Bulaksumur, Sleman, D.I. Yogyakarta 55281
}

\begin{abstract}
Determination of criminal act as crime and violation in special criminal laws have juridical implications of material and formal juridical. Material juridical implications of the establishment of criminal offenses as crimes and violation in special criminal laws outside the Penal Code deals with the problem of "national principle active", "trials of crime", "criminal acts of assistance", "concursus", "prosecution expired", and "shelf implementation of the criminal". While the formal juridical implications of the establishment of criminal offenses as crimes and violations in the special criminal laws outside the Penal Code relating to arrest and detention issues set out in the Code of Criminal Procedure.
\end{abstract}

Keywords: crime, violation, juridical implication.

\section{Intisari}

Penetapan tindak pidana sebagai kejahatan dan pelanggaran dalam undang-undang pidana khusus memiliki implikasi yuridis materiil dan yuridis formal. Penetapan kualifikasi yuridis tindak pidana sebagai kejahatan dan pelanggaran ini diperlukan untuk "menjembatani" berlakunya aturan umum KUHP dan KUHAP terhadap hal-hal yang tidak diatur dalam undang-undang pidana khusus. Implikasi yuridis materiil dari penetapan tindak pidana sebagai kejahatan dan pelanggaran berkaitan dengan masalah "asas nasional aktif", "percobaan tindak pidana", "pembantuan tindak pidana", "perbarengan tindak pidana", "daluwarsa penuntutan", dan "daluwarsa pelaksanaan pidana". Implikasi yuridis formal dari penetapan tindak pidana sebagai kejahatan dan pelanggaran berkaitan dengan masalah penangkapan dan penahanan dalam KUHAP. Kata Kunci: kejahatan, pelanggaran, implikasi yuridis.

\section{Pokok Muatan}

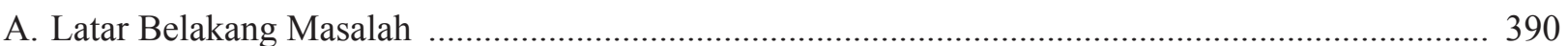

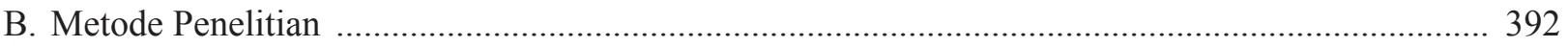

C. Hasil Penelitian dan Pembahasan ................................................................................................ 393

1. Realita Penetapan Tindak Pidana sebagai Kejahatan dan Pelanggaran dalam Undang-Undang Pidana Khusus

2. Implikasi Yuridis Penetapan Tindak Pidana sebagai Kejahatan dan Pelanggaran dalam Undang-Undang Pidana Khusus

D. Kesimpulan

Hibah Penelitian dari Unit Penelitian dan Pengabdian kepada Masyarakat Fakultas Hukum UGM Tahun 2015.

Alamat korespondensi: supriyadi@ugm.ac.id 


\section{A. Latar Belakang Masalah}

Tindak pidana merupakan salah satu bentuk dari "perilaku menyimpang" yang selalu ada dan melekat pada tiap bentuk masyarakat, sehingga tidak ada masyarakat yang sepi dari tindak pidana. Perilaku menyimpang tersebut merupakan suatu ancaman yang nyata atau ancaman terhadap normanorma sosial yang mendasari kehidupan atau keteraturan sosial; dapat menimbulkan ketegangan individual maupun ketegangan-ketegangan sosial; dan merupakan ancaman riil atau potensiil bagi berlangsungnya ketertiban sosial. ${ }^{1}$ Dalam kerangka demikian, Marc Ancel menyatakan bahwa tindak pidana adalah "a human and social problem". Artinya, tindak pidana bukan hanya merupakan masalah sosial, melainkan juga merupakan masalah kemanusiaan. $^{2}$

Benedict S. Alper sebagaimana dikutip oleh Barda Nawawi Arief bahkan menyebut tindak pidana sebagai "the oldest social problem". Benedict S. Alper juga mengemukakan bahwa tidak ada masalah sosial yang mempunyai rekor demikian lama mendapat perhatian dunia luas secara terusmenerus selain daripada fenomena tindak pidana. ${ }^{3}$ Oleh karena itulah wajar apabila Seiichiro Ono menyatakan bahwa tindak pidana merupakan masalah sosial yang tidak hanya menjadi masalah suatu masyarakat tertentu atau masalah nasional, tetapi tindak pidana menjadi masalah yang dihadapi oleh seluruh masyarakat di dunia atau masalah internasional, sehingga tindak pidana disebut sebagai "a universal phenomenon". ${ }^{4}$

Dalam rangka menanggulangi tindak pidana tersebut di atas telah banyak ditempuh dan dilakukan berbagai macam cara. Salah satu upaya penanggulangan tindak pidana itu dilakukan dengan menggunakan hukum pidana dengan sanksinya yang berupa pidana. Upaya penanggulangan tindak pidana dengan menggunakan sanksi pidana pada hakikatnya merupakan cara yang paling tua, setua peradaban manusia itu sendiri. ${ }^{5}$ Namun demikian, penggunaan sanksi pidana ternyata masih diandalkan sebagai sarana penanggulangan tindak pidana. Hal tersebut dapat diketahui dari kebanyakan produk undang-undang dewasa ini yang hampir selalu mencantumkan bab mengenai "ketentuan pidana". Dalam kerangka demikian, seolah-olah dirasakan kurang sempurna atau "hambar" apabila suatu produk undang-undang atau disajikan tanpa ketentuan pidana. Pencantuman bab "ketentuan pidana" tersebut bahkan terkadang dilatarbelakangi oleh suatu sikap atau asumsi bahwa "kurang aman" atau "kurang ada jaminan" apabila suatu produk undang-undang tidak ada ketentuan pidananya. ${ }^{6}$

Produk undang-undang yang memuat "ketentuan pidana" pada hakikatnya dapat dikualifikasikan sebagai undang-undang pidana khusus. Hal tersebut sebagaimana dikemukakan oleh Sudarto bahwa undang-undang pidana khusus merupakan undangundang pidana selain Kitab Undang-Undang Hukum Pidana (KUHP) yang merupakan induk peraturan hukum pidana. $^{7}$ Sudarto menjelaskan lebih lanjut bahwa apabila undang-undang pidana dibagi menurut sifatnya, maka undang-undang pidana itu dapat dibagi menjadi undang-undang pidana "dalam arti sesungguhnya" dan peraturanperaturan hukum pidana dalam undang-undang tersendiri. Undang-undang pidana "dalam arti sesungguhnya" merupakan undang-undang yang menurut tujuannya dimaksudkan mengatur hak memberi pidana dari negara dan contohnya adalah KUHP. Sedangkan peraturan-peraturan hukum pidana dalam undang-undang tersendiri merupakan peraturan-peraturan yang hanya dimaksudkan untuk

\footnotetext{
Barda Nawawi Arief, 2010, Kebijakan Legislatif dalam Penanggulangan Kejahatan Dengan Pidana Penjara, Genta Publishing, Yogyakarta, hlm. 11. Pernyataan ini menyitir dari pendapatnya Saparinah Sadli yang mengemukakan lebih lanjut bahwa yang dimaksud dengan "perilaku menyimpang" adalah "tingkah laku yang dinilai menyimpang dari aturan-aturan normatif yang berlaku".

Marc Ancel, 1965, Social Defence: A Modern Approach to Criminal Problems, Routledge \& Paul Kegan, London, hlm. 99.

Barda Nawawi Arief, Loc.cit.

Ibid., hlm. 12.

Barda Nawawi Arief, 1998, Beberapa Aspek Kebijakan Penegakan dan Pengembangan Hukum Pidana, Citra Aditya Bakti, Bandung, hlm. 39. Ibid., hlm. 138-139.

Sudarto, 2006, Kapita Selekta Hukum Pidana, Alumni, Bandung, hlm. 59-60.
} 
memberi sanksi pidana terhadap aturan-aturan mengenai salah satu bidang yang terletak di luar hukum pidana, misalnya Undang-Undang Pokok Agraria. ${ }^{8}$ Bertolak dari pandangan Sudarto tersebut dapat disimpulkan bahwa undang-undang pidana khusus di luar KUHP mencakup undang-undang pidana dalam arti sesungguhnya dan undangundang administrasi yang di dalamnya memuat ketentuan pidana.

Dengan menggunakan nomenklatur yang berbeda, Indriyanto Seno Adji menyebut undangundang pidana khusus di luar KUHP dalam arti sesungguhnya di atas sebagai hukum pidana khusus yang bersifat "intra aturan pidana". Undang-undang pidana yang dapat dimasukkan sebagai hukum pidana khusus yang bersifat intra aturan pidana yaitu Undang-Undang Tindak Pidana Korupsi, Undang-Undang Tindak Pidana Pencucian Uang, dan Undang-Undang Pemberantasan Tindak Pidana Terorisme. Sedangkan undang-undang administrasi yang di dalamnya memuat ketentuan pidana disebut sebagai hukum pidana khusus yang bersifat "ekstra aturan pidana". Undang-undang pidana yang dapat dimasukkan sebagai hukum pidana khusus yang bersifat ekstra aturan pidana yaitu Undang-Undang Kehutanan, Undang-Undang Keimigrasian, Undang-Undang Perbankan, Undang-Undang Pasal Modal, Undang-Undang Ketenagalistrikan dan lain-lain. Undang-undang pidana yang bersifat ekstra aturan pidana inilah yang disebut sebagai "Adminitrative Penal Law" atau hukum pidana administrasi.

Dalam bab "ketentuan pidana" undangundang pidana khusus di luar KUHP yang bersifat intra aturan pidana maupun ekstra aturan pidana pada dasarnya dirumuskan perbuatan-perbuatan yang dilarang dan diancam dengan sanksi pidana atau sering dikenal dengan istilah "tindak pidana" atau "perbuatan pidana". Berkaitan dengan hal ini, Eddy O.S. Hiariej yang mengutip bukunya Piers
Beire dan James Messerschmidt mengemukakan bahwa tindak pidana atau perbuatan pidana itu disebut sebagai legal definition of crime yang dapat dibedakan menjadi mala in se dan mala prohibita. Mala in se yang disebut sebagai kejahatan merupakan perbuatan-perbuatan yang sejak awal dirasakan sebagai suatu ketidakadilan karena bertentangan dengan kaidah-kaidah dalam masyarakat sebelum ditetapkan oleh undang-undang sebagai suatu perbuatan pidana. Sedangkan mala prohobita yang diidentikkan dengan pelanggaran merupakan perbuatan-perbuatan yang ditetapkan oleh undangundang sebagai suatu ketidakadilan. ${ }^{10}$

Eddy O.S. Hiariej mengemukakan lebih lanjut bahwa dalam kosa kata lain perbedaan antara mala in se dan mala prohibita oleh para ahli hukum dibedakan menjadi felonies dan misdemeanors. Demikian pula dalam kosa kata Belanda yang membedakan kualifikasi perbuatan pidana ke dalam misdrijf (kejahatan) dan overtreding (pelanggaran). Dalam konteks ini, misdrijf lebih mengarah kepada rechtsdelicten (mala in se), sedangkan overtreding lebih mengarah kepada wetsdelicten (mala prohibita). ${ }^{11}$

KUHP yang merupakan induk peraturan hukum pidana di Indonesia masih membedakan tindak pidana menjadi kejahatan dan pelanggaran. Penetapan tindak pidana sebagai kejahatan diatur dalam Buku Kedua KUHP, sedangkan penetapan tindak pidana sebagai pelanggaran ditempatkan dalam Buku Ketiga KUHP. Hal tersebut berbeda dengan RUU KUHP (2012) yang ternyata tidak lagi mengkualifikasikan tindak pidana menjadi kejahatan dan pelanggaran. Dalam Penjelasan Umum RUU KUHP disebutkan bahwa RUU KUHP tidak membedakan lagi antara tindak pidana (strafbaarfeit) berupa kejahatan (misdrijven) dan tindak pidana pelanggaran (overtredingen). Untuk keduanya dipakai istilah tindak pidana. Dengan demikian, RUU KUHP hanya terdiri atas 2 (dua)

Ibid., hlm. 63-64.

Indriyanto Seno Adji, “Administrative Penal Law: Kearah Konstruksi Pidana Limitatif”, Makalah, Pelatihan Hukum Pidana dan Kriminologi, Yogyakarta, 23-27 Februari 2014.

10 Eddy O.S. Hiariej, 2014, Prinsip-Prinsip Hukum Pidana, Cahaya Atma Pustaka, Yogyakarta, hlm. 101-102.

11 Ibid., hlm. 102. 
buku yaitu Buku Kesatu memuat Ketentuan Umum dan Buku Kedua yang memuat ketentuan tentang Tindak Pidana. Adapun Buku Ketiga KUHP yang mengatur tentang tindak pidana pelanggaran dihapus dan materinya secara selektif ditampung ke dalam Buku Kedua dengan kualifikasi Tindak Pidana.

Alasan penghapusan tersebut didasarkan atas kenyataan bahwa secara konseptual perbedaan antara kejahatan sebagai "rechtsdelict" dan pelanggaran sebagai "wetsdelict" ternyata tidak dapat dipertahankan, karena dalam perkembangannya tidak sedikit beberapa "rechtsdelict" dikualifikasikan sebagai pelanggaran dan sebaliknya beberapa perbuatan yang seharusnya merupakan "wetsdelict" dirumuskan sebagai kejahatan, hanya karena diperberat ancaman pidananya. Kenyataan juga membuktikan bahwa persoalan berat ringannya kualitas dan dampak tindak pidana kejahatan dan pelanggaran juga relatif, sehingga kriteria kualitatif semacam ini dalam kenyataannya tidak lagi dapat dipertahankan secara konsisten.

Terlepas dari perbedaan antara KUHP dan RUU KUHP menyangkut penetapan tindak pidana sebagai kejahatan dan pelanggaran di atas, tetapi perlu diketahui bahwa KUHP itu merupakan ius constitutum atau hukum positif yang masih berlaku di Indonesia, sedangkan RUU KUHP merupakan ius constituendum atau hukum yang akan berlaku di masa mendatang. Bertolak dari pokok-pokok pemikiran di atas terdapat dua permasalahan yang dicari jawabannya dalam penelitian ini. Pertama, bagaimanakah realita penetapan tindak pidana sebagai kejahatan dan pelanggaran dalam undangundang pidana khusus di luar KUHP selama ini? Kedua, bagaimanakah implikasi yuridis dari penetapan tindak pidana sebagai kejahatan dan pelanggaran dalam undang-undang pidana khusus di luar KUHP?

\section{B. Metode Penelitian}

Metode penelitian dapat dimaknai sebagai suatu pendekatan umum ke arah fenomena yang telah dipilih oleh peneliti untuk diselidiki. Hal ini berarti bahwa metode penelitian merupakan sejenis logika yang mengarahkan penelitian. Pengertian metode penelitian tersebut sesuai dengan hakikat penelitian sebagai suatu penemuan informasi melalui prosedur tertentu atau prosedur terstandar. ${ }^{12}$

Dilihat dari sumber datanya, penelitian ini merupakan penelitian hukum normatif, karena menekankan pada penggunaan data sekunder. Dilihat dari sifatnya, penelitian ini dapat dikualifikasikan sebagai penelitian deskriptif, karena dimaksudkan untuk mengungkapkan data yang seteliti mungkin tentang keadaan atau gejala berkaitan dengan penetapan tindak pidana sebagai kejahatan dan pelanggaran dalam undang-undang pidana pidana khusus. Dilihat dari bentuknya, penelitian ini dapat dimasukkan sebagai penelitian preskriptif, karena ditujukan pula untuk mendapatkan saran atau masukan berkaitan dengan kebijakan yang diharapkan (ius constituendum) mengenai penetapan tindak pidana sebagai kejahatan dan pelanggaran dalam undang-undang pidana khusus. ${ }^{13}$ Penelitian hukum normatif dapat mencakup penelitian terhadap asas-asas hukum, penelitian terhadap sistematik hukum, penelitian terhadap taraf sinkronisasi vertikal dan horizontal, perbandingan hukum, dan sejarah hukum. ${ }^{14}$ Penelitian ini merupakan penelitian terhadap taraf sinkronisasi horizontal yang tujuannya adalah mengungkapkan realitas tentang keserasian peraturan perundang-undangan yang sederajat menyangkut bidang yang sama, yaitu penetapan tindak pidana sebagai kejahatan dan pelanggaran. ${ }^{15}$

Bahan penelitian yang digunakan dalam penelitian hanya meliputi data sekunder, yaitu data yang bersumber dari bahan-bahan kepustakaan. ${ }^{16}$

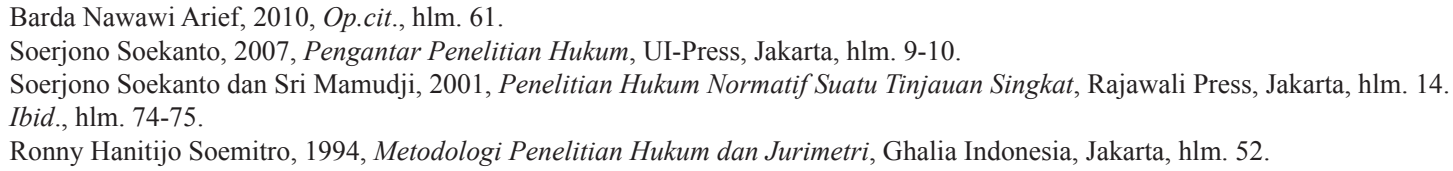


Data sekunder dalam penelitian ini dibedakan lebih lanjut ke dalam bahan hukum primer, bahan hukum sekunder maupun bahan hukum tersier. ${ }^{17}$ Bahan hukum primer sebagai bahan hukum yang utama dan mengikat terdiri dari undang-undang pidana khusus yang bersifat intra aturan pidana dan ekstra aturan pidana

Cara pengumpulan data sekunder dalam penelitian ini dilakukan melalui penelitian kepustakaan, sedangkan alat pengumpulan dilakukan dengan studi dokumen. Dalam penelitian ini terdapat dua metode pendekatan digunakan untuk mencari dan menemukan jawaban permasalahan. Pertama, pendekatan undang-undang atau statute approach yang dilakukan dengan cara menelaah semua peraturan perundang-undangan yang berkaitan dengan permasalahan penelitian. ${ }^{18}$ Kedua, pendekatan konseptual atau conceptual approach. Pendekatan konseptual merupakan pendekatan yang bertolak dari pandangan-pandangan dan doktrindoktrin yang berkembang dalam ilmu hukum. Pemahaman terhadap pandangan-pandangan dan doktrin-doktrin tersebut dapat menjadi sandaran dalam membangun dan memecahkan permasalahan penelitian. ${ }^{19}$ Analisis data dalam penelitian ini dilakukan secara kualitatif.

\section{Hasil Penelitian dan Pembahasan}

1. Realita Penetapan Tindak Pidana sebagai Kejahatan dan Pelanggaran dalam Undang-Undang Pidana Khusus

Dalam penelitian ini dikaji 7 (tujuh) undangundang pidana khusus yang bersifat intra aturan pidana. Ketujuh undang-undang tersebut adalah:

a. Undang-Undang Nomor 7/Drt./1955 tentang Pengusutan, Penuntutan dan Peradilan Tindak Pidana Ekonomi;

b. Undang-Undang Nomor 31 Tahun 1999 jo. Undang-Undang Nomor 20 Tahun 2000 tentang Pemberantasan Tindak Pidana Korupsi; c. Undang-Undang Nomor 15 Tahun 2003 tentang Penetapan Peraturan Pemerintah Pengganti Undang-Undang Nomor 1 Tahun 2002 tentang Pemberantasan Tindak Pidana Terorisme Menjadi Undang-Undang;

d. Undang-Undang Nomor 21 Tahun 2007 tentang Pemberantasan Tindak Pidana Perdagangan Orang;

e. Undang-Undang Nomor 8 Tahun 2010 tentang Pencegahan dan Pemberantasan Tindak Pidana Pencucian Uang;

f. Undang-Undang Nomor 9 Tahun 2013 tentang Pencegahan dan Pemberantasan Tindak Pidana Pendanaan Terorisme; dan

g. Undang-Undang Nomor 18 Tahun 2013 tentang Pencegahan dan Pemberantasan Perusakan Hutan.

Hasil kajian terhadap ketujuh undang-undang pidana khusus yang bersifat intra aturan pidana di atas menunjukkan bahwa undang-undang pidana khusus a quo tidak semuanya menetapkan dan membedakan tindak pidananya menjadi kejahatan dan pelanggaran. Undang-undang pidana khusus yang bersifat intra aturan pidana yang menetapkan dan membedakan tindak pidananya menjadi kejahatan dan pelanggaran hanya dijumpai dalam Undang-Undang Nomor 7/Drt/1955 atau UndangUndang Tindak Pidana Ekonomi.

Meskipun undang-undang pidana khusus yang bersifat intra aturan pidana tidak menetapkan dan membedakan tindak pidana menjadi kejahatan dan pelanggaran, namun dalam undang-undang pidana khusus a quo membuat aturan khusus menyangkut ancaman pidana terhadap percobaan dan/atau pembantuan tindak pidana. Aturan khusus tersebut dapat ditemukan dan dilihat dalam Pasal 15 Undang-Undang Nomor 31 Tahun 1999 jo. Undang-Undang Nomor 20 Tahun 2001, Pasal 15 Undang-Undang Nomor 15 Tahun 2003 jo. Peraturan Pemerintah Pengganti Undang-Undang Nomor 1 Tahun 2002, Pasal 10 Undang-Undang 
Nomor 21 Tahun 2007, Pasal 10 Undang-Undang Nomor 8 Tahun 2010, dan Pasal 5 Undang-Undang Nomor 9 Tahun 2013.

Aturan khusus mengenai ancaman pidana untuk percobaan dan pembantuan tindak pidana dalam undang-undang di atas pada hakikatnya merupakan penyimpangan dari aturan umum pemidanaan percobaan tindak pidana dalam Pasal 54 ayat (2) KUHP dan Pasal 57 ayat (1) KUHP, dimana ancaman pidananya dikurangi sepertiga dari maksimum ancaman pidana pokok. Pasal 54 ayat (2) KUHP menyatakan bahwa "maksimum pidana pokok terhadap kejahatan, dalam hal percobaan dapat dikurangi sepertiga". Sedangkan Pasal 57 ayat (1) KUHP menyatakan bahwa "dalam hal pembantuan, maksimum pidana pokok terhadap kejahatan, dikurangi sepertiga".

Dalam penelitian ini dikaji undang-undang pidana khusus yang bersifat ekstra aturan pidana atau undang-undang administrasi yang di dalamnya memuat ketentuan pidana yang diterbitkan sejak tahun 2005 sampai dengan tahun 2014. Hasil penelusuran undang-undang pidana khusus a quo dapat dipaparkan dalam tabel di bawah ini.

Tabel 1. Penetapan Tindak Pidana Sebagai Kejahatan dalam Undang-Undang Ekstra Aturan Pidana

\begin{tabular}{|c|c|c|c|c|c|}
\hline Tahun & $\begin{array}{l}\text { Jumlah } \\
\text { Undang- } \\
\text { Undang }\end{array}$ & $\begin{array}{l}\text { Undang- } \\
\text { Undang } \\
\text { Memuat } \\
\text { Ketentuan } \\
\text { Pidana }\end{array}$ & $\begin{array}{c}\text { Tidak } \\
\text { Menetapkan } \\
\text { Kejahatan } \\
\text { dan } \\
\text { Pelanggaran }\end{array}$ & $\begin{array}{l}\text { Menetapkan } \\
\text { Kejahatan dan } \\
\text { Pelanggaran }\end{array}$ & Keterangan \\
\hline 2005 & 14 & 1 & 1 & 0 & - \\
\hline 2006 & 23 & 5 & 5 & 0 & - \\
\hline 2007 & 22 & 4 & 4 & 0 & - \\
\hline 2008 & 56 & 16 & 14 & 2 & $\begin{array}{l}\text { Undang-Undang Nomor } 8 \text { Tahun } \\
2008 \text { dan Undang-Undang } \\
\text { Nomor } 44 \text { Tahun } 2008\end{array}$ \\
\hline 2009 & 52 & 19 & 17 & 2 & $\begin{array}{l}\text { Undang-Undang Nomor } 18 \\
\text { Tahun } 2009 \text { dan Undang-Undang } \\
\text { Nomor } 22 \text { Tahun } 2009\end{array}$ \\
\hline 2010 & 13 & 2 & 2 & 0 & - \\
\hline 2011 & 24 & 13 & 11 & 2 & $\begin{array}{l}\text { Undang-Undang Nomor } 7 \text { Tahun } \\
2011 \text { dan Undang-Undang } \\
\text { Nomor } 23 \text { Tahun } 2011\end{array}$ \\
\hline 2012 & 24 & 6 & 5 & 1 & $\begin{array}{l}\text { Undang-Undang Nomor } 8 \text { Tahun } \\
2012\end{array}$ \\
\hline 2013 & 24 & 3 & 3 & 0 & - \\
\hline 2014 & 42 & 15 & 15 & 0 & - \\
\hline Jumlah & 294 & 84 & 77 & 7 & - \\
\hline
\end{tabular}

Sumber: Data Olahan Penulis.

Berdasarkan tabel di atas dapat diketahui bahwa selama 2005-2014 telah diterbitkan 294 (dua ratus sembilan puluh empat) undang-undang, dimana sebanyak 84 (delapan puluh empat) undangundang yang di dalamnya memuat ketentuan pidana.
Namun demikian, dari 84 (delapan puluh empat) undang-undang yang memuat ketentuan pidana tersebut ternyata hanya terdapat 7 (tujuh) undangundang pidana yang membedakan dan menetapkan tindak pidana sebagai kejahatan dan pelanggaran. 
Sedangkan 77 (tujuh puluh tujuh) undang-undang pidana tidak menetapkan tindak pidana sebagai kejahatan dan pelanggaran.

Ketujuh undang-undang pidana yang diterbitkan selama tahun 2005-2024 dan menetapkan tindak pidana sebagai kejahatan dan pelanggaran yaitu:

a. Undang-Undang Nomor 18 Tahun 2008 tentang Pengelolaan Sampah;

b. Undang-Undang Nomor 44 Tahun 2008 tentang Pornograf;

c. Undang-Undang Nomor 18 Tahun 2009 tentang Peternakan dan Kesehatan Hewan;

d. Undang-Undang Nomor 22 Tahun 2009 tentang Lalu Lintas dan Angkutan Jalan;

e. Undang-Undang Nomor 7 Tahun 2011 tentang Mata Uang;

f. Undang-Undang Nomor 23 Tahun 2011 tentang Pengelolaan Zakat; dan

g. Undang-Undang Nomor 8 Tahun 2012 tentang Pemilihan Umum Dewan Perwakilan Rakyat, Dewan Perwakilan Daerah dan Dewan Perwakilan Rakyat Daerah.

Meskipun sebagian besar undang-undang pidana khusus yang bersifat ekstra aturan pidana di atas tidak menetapkan dan membedakan tindak pidana menjadi kejahatan dan pelanggaran, namun terdapat satu undang-undang pidana khusus yang di dalamnya membuat aturan khusus menyangkut ancaman pidana terhadap percobaan dan/atau pembantuan tindak pidana, yaitu Undang-Undang Nomor 35 Tahun 2009. Dalam Pasal 132 ayat (1) undang-undang ini ditegaskan bahwa "percobaan atau permufakatan jahat untuk melakukan tindak pidana Narkotika dan Prekursor Narkotika sebagaimana dimaksud dalam Pasal 111, Pasal 112, Pasal 113, Pasal 114, Pasal 115, Pasal 116, Pasal 117, Pasal 118, Pasal 119, Pasal 120, Pasal 121, Pasal 122, Pasal 123, Pasal 124, Pasal 125, Pasal 126, dan Pasal 129, pelakunya dipidana dengan pidana penjara yang sama sesuai dengan ketentuan sebagaimana dimaksud dalam pasal-pasal tersebut".
2. Implikasi Yuridis Penetapan Tindak Pidana sebagai Kejahatan dan Pelanggaran dalam Undang-Undang Pidana Khusus

\section{a. Implikasi Yuridis Materiil}

Implikasi yuridis materiil dari penetapan tindak pidana sebagai kejahatan dan pelanggaran dalam dalam undangundang pidana khusus mengandung arti bahwa undang-undang pidana khusus tetap terikat pada aturan umum KUHP mengenai akibat-akibat yuridis dari pembedaan antara "kejahatan" dan "pelanggaran". Menurut Barda Nawawi Arief, penetapan kualifikasi yuridis tindak pidana sebagai kejahatan dan pelanggaran ini diperlukan untuk "menjembatani" berlakunya aturan umum KUHP terhadap hal-hal yang tidak diatur dalam undang-undang pidana khusus di luar KUHP. Dengan demikian identik dengan penetapan kualifikasi yuridis terhadap suatu perbuatan sebagai "Tindak Pidana Ekonomi" dalam Undang-Undang Nomor 7/Drt/1955 atau sebagai "Tindak Pidana Korupsi” dalam Undang-Undang Nomor 31 Tahun 1999 sebagaimana telah diubah dengan UndangUndang Nomor 20 Tahun 2001. ${ }^{20}$

Penetapan kualifikasi yuridis terhadap suatu perbuatan sebagai "Tindak Pidana Ekonomi" diaturdan dirumuskan dalam Pasal $1 \mathrm{sub}$ 3e Undang-Undang Nomor 7/Drt/1955 yang pada intinya menegaskan "apabila UndangUndang Tindak Pidana Ekonomi (UndangUndang Nomor 7/Drt/1955) menyebut/ menyatakan bahwa suatu delik adalah "Tindak Pidana Ekonomi", maka berlakulah ketentuan dalam Undang-Undang Tindak Pidana Ekonomi itu". Sedangkan penetapan kualifikasi yuridis terhadap suatu perbuatan sebagai "Tindak Pidana Korupsi" diatur dan dirumuskan dalam Pasal 14 Undang-Undang Nomor 31 Tahun 1999 sebagaimana telah

20 Barda Nawawi Arief, 2007, Masalah Penegakan Hukum dan Kebijakan Hukum Pidana dalam Penanggulangan Kejahatan, Kencana, Jakarta, hlm. 147. 
diubah dengan Undang-Undang Nomor 20 Tahun 2001 yang pada hakikatnya menegaskan "apabila undang-undang di luar Undang-Undang Pemberantasan Tindak Pidana Korupsi (Undang-Undang Nomor 31 Tahun 1999) menyebut/menyatakan bahwa suatu delik adalah "Tindak Pidana Korupsi", maka berlakulah ketentuan Undang-Undang Pemberantasan Tindak Pidana Korupsi itu".

Demikian pulalah dengan ketentuan KUHP, karena aturan umum KUHP membedakan antara "aturan umum untuk kejahatan" dan "aturan umum untuk pelanggaran", maka apabila aturan umum KUHP itu akan diberlakukan pula terhadap undang-undang pidana di luar KUHP, sehingga undang-undang pidana di luar KUHP tersebut juga harus menyebutkan kualifikasi yang jelas dari tindak pidana yang diaturnya, apakah merupakan "kejahatan" atau "pelanggaran". ${ }^{21}$ Hal ini merupakan conditio sine qua non dari ketentuan Pasal 103 KUHP yang menggariskan bahwa "ketentuan-ketentuan dalam Bab I sampai dengan Bab VIII buku ini juga berlaku bagi perbuatan-perbuatan yang oleh ketentuan perundang-undangan lainnya diancam dengan pidana, kecuali jika oleh undang-undang ditentukan lain".

Apabila dicermati dan dikaji lebih mendalam, maka implikasi yuridis materiil dari penetapan tindak pidana sebagai kejahatan dan pelanggaran dalam dalam undang-undang pidana khusus, baik yang bersifat intra aturan pidana maupun ekstra aturan pidana, akan berkaitan dengan masalah "asas nasional aktif", "percobaan tindak pidana", "pembantuan tindak pidana", "perbarengan tindak pidana", "daluwarsa penuntutan", dan "daluwarsa pelaksanaan pidana".

\section{1) Asas Nasional Aktif}

Asas nasional aktif sering disebut dengan asas personalitas. Asas ini antara lain menyatakan bahwa peraturan hukum pidana Indonesia berlaku bagi setiap warga negara Indonesia yang melakukan tindak pidana di luar negeri. Dengan demikian, peraturan hukum pidana Indonesia itu seolah-olah mengikuti orangnya, yaitu warga negara Indonesia. Oleh karena itulah asas tersebut dinamakan asas nasional aktif. ${ }^{22}$ Dalam konteks asas nasional aktif, implikasi yuridis materiil pembedaan tindak pidana sebagai kejahatan dan pelanggaran akan berkaitan dengan Pasal 5 ayat (1) ke-2 KUHP yang menyatakan bahwa "aturan pidana dalam perundangundangan Indonesia berlaku bagi warga negara yang di luar Indonesia melakukan salah satu perbuatan yang oleh suatu aturan pidana dalam perundang-undangan Indonesia dipandang sebagai kejahatan sedangkan menurut perundang-undangan negara dimana perbuatan dilakukan, diancam dengan pidana".

Penerapan Pasal 5 ayat (1) ke-2 KUHP ini harus memenuhi asas kriminalitas ganda atau "double criminality principle", dimana peraturan hukum pidana Indonesia maupun peraturan hukum pidana tempat dilakukannya perbuatan tersebut merupakan perbuatan yang diancam pidana. Dengan kata lain, perbuatan tersebut menurut hukum pidana Indonesia maupun hukum pidana negara lain dipandang sebagai tindak pidana. Namun demikian, 
apabila dicermati secara mendalam rumusan Pasal 5 ayat (1) ke-2 KUHP tersebut mensyaratkan bahwa tindak pidana yang dimaksudkan dalam pasal ini harus memiliki kualifikasi yuridis sebagai "kejahatan". Dengan demikian, secara a contrario asas nasional aktif dalam Pasal 5 ayat (1) ke-2 KUHP tidak bisa diberlakukan terhadap tindak pidana yang kualifikasi yuridisnya merupakan "pelanggaran". Kesimpulannya, tanpa adanya penegasan penetapan tindak pidana dalam undang-undang pidana khusus sebagai kejahatan dan pelanggaran, maka penerapan asas nasional aktif tersebut akan sulit diterapkan ketika tindak pidana dalam undang-undang-undang pidana khusus tersebut dilakukan oleh warga negara Indonesia di negara lain.

\section{2) Percobaan Tindak Pidana}

Menurut Moeljatno, percobaan tindak pidana merupakan delik selesai dan berdiri sendiri. Percobaan tindak pidana merupakan dasar memperluas dapat dipidananya perbuatan (tatbestand-ausdehnungsgrund). Dengan kata lain, percobaan tindak pidana merupakan delicta sui generis atau delik yang berdiri sendiri atau delik selesai namun bentuknya istimewa. Pandangan demikian didasarkan pada tiga alasan, yaitu dalam hukum pidana Indonesia harus dipisahkan antara perbuatan pidana dan pertanggungjawaban pidana, beberapa percobaan tindak pidana dalam KUHP dirumuskan sebagai delik selesai seperti Pasal 104, Pasal 106, Pasal 107, dan hukum adat tidak mengenal perbuatan pidana yang dirumuskan sebagai percobaan. ${ }^{23}$
Eddy O.S. Hiariej memiliki pandangan yang berbeda, bahwa di satu sisi percobaan tindak pidana merupakan delik yang tidak selesai dan bukan merupakan delik mandiri, namun di sisi lain percobaan tindak pidana merupakan dasar memperluas dapat dipidananya perbuatan. ${ }^{24}$ Pengaturan percobaan tindak pidana terdapat dalam Pasal 53 KUHP dan Pasal 54 KUHP. Pengertian percobaan tindak pidana tersirat dari elemen-elemennya yang dirumuskan dalam Pasal 53 ayat (1) KUHP, bahwa "mencoba melakukan kejahatan dipidana, jika niat untuk itu telah ternyata dari adanya permulaan pelaksanaan, dan tidak selesainya pelaksanaan itu, bukan semata-mata karena kehendaknya sendiri”. Berdasarkan konstruksi pasal tersebut dapat diketahui adanya tiga syarat percobaan tindak pidana, yaitu niat, permulaan pelaksanaan, dan tidak selesainya pelaksanaan itu, bukan semata-mata karena kehendaknya sendiri.

Pemidanaan terhadap percobaan tindak pidana ditentukan dalam Pasal 53 ayat (2), (3), (4) dan Pasal 54 KUHP. Pertama, maksimum pidana pokok terhadap kejahatan, dalam hal percobaan dapat dikurangi sepertiga. Kedua, jika kejahatan diancam dengan pidana mati dan pidana penjara seumur hidup, dijatuhkan pidana penjara paling lama lima belas tahun. Ketiga, pidana tambahan bagi percobaan adalah sama dengan kejahatan selesai. Sebaliknya, Pasal 54 KUHP menegaskan bahwa "mencoba melakukan pelanggaran tidak dipidana". 
Bertolak dari Pasal 53 KUHP dan Pasal 54 KUHP di atas jelaslah bahwa pembedaan kualifikasi yuridis tindak pidana menjadi kejahatan dan pelanggaran memiliki implikasi yuridis terkait dengan pemidanaan percobaan tindak pidana. Dalam kerangka demikian, percobaan tindak pidana yang dapat dipidana adalah kejahatan, sedangkan percobaan tindak pidana pelanggaran tidak dapat dikenakan pidana. Kesimpulannya, tanpa adanya penegasan penetapan tindak pidana dalam undang-undang pidana khusus di luar KUHP sebagai kejahatan dan pelanggaran, maka pemidanaan terhadap tindak pidana dalam undang-undang pidana khusus tersebut akan menemui kesulitan ketika tindak pidana dalam undangundang-undang pidana khusus tersebut baru merupakan percobaan.

\section{3) Pembantuan Tindak Pidana}

Dalam pembantuan (medeplichtige) terdapat dua pihak yang terdiri dari dua orang atau lebih, yaitu pelaku/ pembuat dan pembantu. Pembantuan diatur dalam Pasal 56 dan Pasal 57 KUHP. Pasal 56 KUHP menyebutkan bahwa dipidana sebagai pembantu (medeplichtige) sesuatu kejahatan:

a) mereka yang sengaja memberi bantuan pada waktu kejahatan dilakukan;

b) mereka yang sengaja memberi kesempatan, sarana atau keterangan untuk melakukan kejahatan.

Berdasarkan Pasal 56 KUHP tersebut, terdapat dua bentuk pembantuan, yaitu pembantuan pada saat kejahatan dilakukan dan pembantuan untuk melakukan kejahatan. Hal ini berarti bahwa pembantuan itu dibe- rikan sebelum kejahatan terjadi, apakah dengan memberikan kesempatan, sarana atau keterangan untuk melakukan kejahatan.

Pemidanaan terhadap pembantuan tindak pidana ditentukan dalam Pasal 57 KUHP yang di dalamnya memuat empat ketentuan pemidanaan.

Pertama, dalam hal pembantuan, maksimum pidana pokok terhadap kejahatan, dikurangi sepertiga. Kedua, jika kejahatan diancam dengan pidana mati dan pidana penjara seumur hidup, dijatuhkan pidana penjara paling lama lima belas tahun. Ketiga, pidana tambahan bagi pembantuan adalah sama dengan kejahatannya sendiri. Keempat, dalam hal menentukan pidana bagi pembantu, yang diperhitungkan hanya perbuatan yang sengaja dipermudah atau diperlancar olehnya, beserta akibat-akibatnya.

Bertolak dari Pasal 57 KUHP di atas jelaslah bahwa pembedaan kualifikasi yuridis tindak pidana menjadi kejahatan dan pelanggaran memiliki implikasi yuridis terkait dengan pemidanaan pembantuan tindak pidana. Dalam kerangka demikian, pembantuan tindak pidana yang dapat dipidana adalah kejahatan, sedangkan secara a contrario pembantuan tindak pidana pelanggaran tidak dapat dikenakan pidana. Kesimpulannya, tanpa adanya penegasan kualifikasi tindak pidana dalam undang-undang pidana khusus sebagai kejahatan dan pelanggaran, maka penerapan pemidanaan terhadap tindak pidana dalam undang-undang pidana khusus tersebut akan menemui kesulitan ketika terjadi pembantuan tindak pidana. 
4) Perbarengan Tindak Pidana

Perbarengan tindak pidana dapat dimaknai sebagai seseorang melakukan satu perbuatan yang melanggar beberapa peraturan hukum pidana, atau melakukan beberapa perbuatan yang masing-masing perbuatan berdiri sendiri yang akan diadili sekaligus, dan salah satu dari perbuatan pidana tersebut belum dijatuhi putusan hakim. Bertolak dari pengertian perbarengan tindak pidana ini dapat diperoleh bentuk perbarengan yang meliputi perbarengan peraturan (concursus idealis/eendaadse samenloop), perbuatan berlanjut (voortgezette handeling), dan perbarengan perbuatan (concursus realis/meerdaadse samenloop)..$^{25}$

Menurut sistematika KUHP, pengaturan tentang perbarengan tindak pidana merupakan ketentuan yang berkaitan dengan ukuran dalam menentukan pidana (straftoemeting) yang mempunyai kecenderungan pemberatan pidana. ${ }^{26}$ Perbarengan peraturan diatur dalam Pasal 63 KUHP. Perbuatan berlanjut dirumuskan dalam Pasal 64 KUHP. Pengaturan perbarengan perbuatan dijumpai dalam Pasal 65, 66, 70 dan 70 bis KUHP.

Implikasi yuridis penetapan tindak pidana sebagai kejahatan dan pelanggaran akan berkaitan dengan perbarengan perbuatan. Hal tersebut dapat diketahui dari rumusan Pasal 65, 66, 70 dan 70 bis KUHP. Dalam Pasal 65 ayat (1) KUHP disebutkan bahwa dalam hal perbarengan beberapa perbuatan yang harus dipandang sebagai perbuatan yang berdiri sendiri- sendiri, sehingga merupakan beberapa kejahatan, yang diancam dengan pidana pokok yang sejenis, maka hanya dijatuhkan satu pidana. Pasal 65 ayat (2) KUHP menyatakan lebih lanjut bahwa maksimum pidana yang dijatuhkan ialah jumlah maksimum pidana yang diancamkan terhadap perbuatan itu, tetapi tidak boleh lebih dari maksimum pidana yang terberat ditambah sepertiga.

Pasal 66 ayat (1) KUHP menyebutkan bahwa "Dalam hal perbarengan beberapa perbuatan yang harus dipandang sebagai perbuatan yang berdiri sendiri-sendiri, sehingga merupakan beberapa kejahatan, yang diancam dengan pidana pokok yang tidak sejenis, maka dijatuhkan pidana atas tiap-tiap kejahatan, tetapi jumlahnya tidak boleh melebihi maksimum pidana yang terberat ditambah sepertiga". Pasal 70 ayat (1) KUHP menyebutkan bahwa, "Jika ada perbarengan seperti yang dimaksudkan dalam Pasal 65 dan 66, baik perbarengan pelanggaran dengan kejahatan, maupun pelanggaran dengan pelanggaran, maka untuk tiaptiap pelanggaran dijatuhkan pidana sendiri-sendiri tanpa dikurangi". Pasal 70 ayat (2) KUHP menyatakan lebih lanjut bahwa mengenai pelanggaran, jumlah lamanya kurungan, paling banyak adalah satu tahun empat bulan, sedangkan jumlah lamanya kurungan pengganti, paling banyak adalah delapan bulan. Dalam Pasal 70 bis KUHP ditentukan secara khusus bahwa dalam menggunakan Pasal 65, 66 dan 70 KUHP, kejahatan-kejahatan

\footnotetext{
25 Aruan Sakidjo dan Bambang Poernomo, 1990, Hukum Pidana: Dasar Aturan Umum Hukum Pidana Kodifikasi, Ghalia Indonesia, Jakarta, hlm. $169-170$

$26 \quad$ Ibid., hlm. 169.
} 
tersebut dalam Pasal 302 ayat (1), 352, 364, 373, 379, dan 482 KUHP dianggap sebagai pelanggaran, tetapi dengan pengertian bahwa, jika dijatuhkan pidana-pidana penjara atas kejahatan itu, jumlahnya paling banyak adalah delapan bulan. Bertolak dari Pasal 65, 66, 70 dan 70 bis KUHP di atas jelaslah bahwa pembedaan kualifikasi yuridis tindak pidana menjadi kejahatan dan pelanggaran memiliki implikasi yuridis terkait dengan mekanisme pemidanaan perbarengan perbuatan (concursus realis).

\section{5) Daluwarsa Penuntutan}

Latar belakang pemikiran diaturnya daluwarsa penuntutan tidak bisa dilepaskan dari kemampuan daya ingat manusia dan keadaan alam yang memungkinkan petunjuk alat bukti lenyap atau tidak memiliki nilai untuk hukum pembuktian. Daya ingat manusia baik sebagai terdakwa ataupun sebagai saksi seringkali tidak mampu untuk menggambarkan kembali atas kejadian masa lalu. Akibatnya, bahan pembuktian yang diperlukan dalam perkara semakin sulit dipertanggungjawabkan yang disebabkan oleh kerusakan dan lainlainnya. Oleh karena itu, kemanfaatan untuk menuntut perkara pidana yang dapat diragukan kebenarannya karena peristiwanya sudah terlalu lama terjadi, akan lebih berfaedah untuk tidak menuntut berhubung dengan alasan tenggang waktu. Dengan demikian, pembentuk undang-undang memilih kebijaksanaan wewenang menuntut hapus karena daluwarsa dengan tenggang waktu tertentu. ${ }^{27}$

Tenggang waktu daluwarsa pe- nuntutan ditentukan dalam Pasal 78 ayat (1) KUHP yang menegaskan bahwa kewenangan menuntut pidana hapus karena daluwarsa:

a) mengenai semua pelanggaran dan kejahatan yang dilakukan dengan percetakan, sesudah satu tahun;

b) mengenai kejahatan yang diancam dengan denda, kurungan atau pidana penjara paling lama tiga tahun, sesudah enam tahun;

c) mengenai kejahatan yang diancam dengan pidana penjara lebih dari tiga tahun, sesudah dua belas tahun;

d) mengenai kejahatan yang diancam dengan pidana mati atau pidana penjara seumur hidup, sesudah delapan belas tahun.

Bertolak dari Pasal 78 ayat (1) KUHP di atas jelaslah bahwa pembedaan kualifikasi yuridis tindak pidana menjadi kejahatan dan pelanggaran memiliki implikasi yuridis terkait dengan penghitungan tenggang waktu daluwarsa penuntutan. Dalam kerangka demikian, lamanya tenggang waktu daluwarsa penuntutan atas tindak pidana berupa pelanggaran lebih pendek dibandingkan dengan lamanya tenggang daluwarsa penuntutan untuk tindak pidana kejahatan. Demikian pula, tindak pidana kejahatan yang diancam dengan pidana yang ringan, maka lamanya tenggang waktu daluwarsa penuntutan akan lebih pendek dibandingkan dengan tindak pidana kejahatan yang diancam dengan pidana penjara yang berat.

6) Daluwarsa Pelaksanaan Pidana

Pembentuk undang-undang ter- 
nyata tidak hanya mengambil kebijaksanaan menyangkut daluwarsa penuntutan, melainkanjuga mengambil kebijaksanaan tenggang waktu daluwarsa yang dapat menghapuskan atau menggugurkan pelaksanaan pidana. Hal tersebut dinyatakan dalam Pasal 84 ayat (1) KUHP, bahwa kewenangan menjalankan pidana hapus karena daluwarsa. Dalam Pasal 84 ayat (2) KUHP dijelaskan lebih lanjut bahwa tenggang daluwarsa mengenai semua pelanggaran lamanya dua tahun, mengenai kejahatan yang dilakukan dengan sarana percetakan lamanya lima tahun, dan mengenai kejahatankejahatan lainnya lamanya sama dengan tenggang daluwarsa bagi penuntutan, ditambah sepertiga.

Bertolak dari Pasal 84 ayat (2) KUHP di atas jelaslah bahwa pembedaan kualifikasi yuridis tindak pidana menjadi kejahatan dan pelanggaran juga memiliki implikasi yuridis terkait dengan penghitungan tenggang waktu daluwarsa pelaksanaan pidana. Dalam kerangka demikian, lamanya tenggang waktu daluwarsa pelaksanaan pidana atas tindak pidana berupa pelanggaran lebih pendek dibandingkan dengan lamanya tenggang daluwarsa pelaksanaan pidana untuk tindak pidana kejahatan. Demikian pula, tindak pidana kejahatan yang diancam dengan pidana yang ringan, maka lamanya tenggang waktu daluwarsa pelaksanaan pidana akan lebih pendek dibandingkan dengan tindak pidana kejahatan yang diancam dengan pidana penjara yang berat.

\section{b. Implikasi Yuridis Formal}

Implikasi yuridis formal dari penetapan tindak pidana sebagai kejahatan dan pelanggaran dalam dalam undang-undang pidana khusus, baik yang bersifat intra aturan pidana maupun ekstra aturan pidana, mengandung arti bahwa undang-undang pidana khusus di luar KUHP, terikat pada aturan umum yang terdapat dalam UndangUndang Nomor 8 Tahun 1981 tentang Hukum Acara Pidana atau Kitab Undang-Undang Hukum Acara Pidana (KUHAP). Menurut Barda Nawawi Arief, penetapan kualifikasi yuridis tindak pidana sebagai kejahatan dan pelanggaran ini memiliki implikasi yuridis formal dengan masalah penangkapan dan penahanan. ${ }^{28}$

\section{1) Penangkapan}

Penangkapan didefinisikan sebagai suatu tindakan penyidik berupa pengekangan sementara waktu kebebasan tersangka atau terdakwa apabila terdapat cukup bukti guna kepentingan penyidikan atau penuntutan dan atau peradilan. ${ }^{29}$ Menurut Pasal 17 KUHAP, bahwa penangkapan dilakukan terhadap seseorang yang diduga keras melakukan tindak pidana berdasarkan bukti permulaan yang cukup, yaitu bukti permulaan untuk menduga adanya tindak pidana. $^{30}$ Namun demikian, Pasal 19 ayat (2) KUHAP menyebutkan pula bahwa "Terhadap tersangka pelaku pelanggaran tidak diadakan penangkapan kecuali dalam hal ia telah dipanggil secara sah dua kali berturutturut tidak memenuhi penggilan itu tanpa alasan yang sah".

Bertolak dari ketentuan Pasal 19

\footnotetext{
Barda Nawawi Arief, 2008, Bunga Rampai Kebijakan Hukum Pidana: Perkembangan Penyusunan Konsep KUHP Baru, Kencana, Jakarta, hlm. 363-364.

29 Pasal 1 angka 20 KUHAP.

30 Pasal 16 KUHAP dan penjelasannya.
} 
ayat (2) KUHAP dapatlah dikatakan bahwa pada umumnya penangkapan dapat dikenakan terhadap pelaku tindak pidana berupa kejahatan, sedangkan terhadap tersangka pelaku tindak pidana yang merupakan "pelanggaran" hanya merupakan perkecualian. ${ }^{31}$ Tidak adanya penegasan penetapan tindak pidana sebagai kejahatan dan pelanggaran dalam undang-undang pidana khusus di luar KUHP bisa berpotensi menimbulkan disparitas penafsiran mengenai boleh atau tidaknya tersangka dikenakan penangkapan, kecuali undang-undang pidana khusus di luar KUHP tersebut mengatur tersendiri masalah penangkapan, seperti Undang-Undang Nomor 15 Tahun 2003 jo. Peraturan Pemerintah Pengganti Undang-Undang Nomor 1 Tahun 2002 dan Undang-Undang Nomor 35 Tahun 2009.

\section{2) Penahanan}

Penahanan diartikan sebagai penempatan tersangka atau terdakwa di tempat tertentu oleh penyidik atau penuntut umum atau hakim dengan penetapannya. ${ }^{32}$ Menurut Pasal 21 ayat (4) sub a KUHAP menyebutkan bahwa "Penahanan dapat dikenakan terhadap tersangka atau terdakwa yang melakukan tindak pidana (termasuk percobaan dan pembantuan) yang diancam dengan pidana penjara 5 (lima) tahun atau lebih dan delik-delik tertentu yang disebut dalam Pasal 21 ayat (4) sub b KUHAP, meskipun tidak diancam dengan pidana penjara 5 (lima) tahun".

Berdasarkan ketentuan tersebut dapat dikatakan bahwa penahanan terutama dapat dikenakan untuk pelaku "kejahatan" karena menurut sistem yang dianut saat ini pidana penjara hanya diancamkan terhadap tindak pidana kejahatan. Meskipun demikian, menurut Pasal 21 ayat (4) sub b KUHAP ada juga pelaku "pelanggaran" yang dapat dikenakan penahanan. ${ }^{33}$ Tidak adanya penegasan penetapan tindak pidana sebagai kejahatan dan pelanggaran dalam undang-undang pidana khusus ini pun juga bisa berpotensi menimbulkan disparitas penafsiran mengenai boleh atau tidaknya tersangka dikenakan penahanan, kecuali undang-undang pidana khusus tersebut mengatur tersendiri masalah penahanan.

\section{Kesimpulan}

Berdasarkan rumusan permasalahan serta hasil penelitian dan pembahasan di atas dapat dikemukakan dua kesimpulan. Pertama, realita menunjukkan bahwa tidak semua undang-undang pidana khusus melakukan penetapan tindak pidana sebagai kejahatan dan pelanggaran. Hasil kajian terhadap 7 (tujuh) undang-undang pidana khusus yang bersifat intra aturan pidana menunjukkan hanya terdapat 1 (satu) undang-undang yang menetapkan tindak pidana sebagai kejahatan dan pelanggaran yaitu Undang-Undang Nomor 7/ Drt/1955. Hasil kajian terhadap 84 (delapan puluh empat) undang-undang pidana khusus yang bersifat ekstra aturan pidana yang diterbitkan dalam 20052014 hanya ditemukan 7 (tujuh) undang-undang yang menetapkan tindak pidana sebagai kejahatan dan pelanggaran, yaitu Undang-Undang Nomor 8 Tahun 2008, Undang-Undang Nomor 44 Tahun 2008, Undang-Undang Nomor 18 Tahun 2009, Undang-Undang Nomor 22 Tahun 2009, Undang-

\footnotetext{
Barda Nawawi Arief, 2008, Op.cit., hlm. 363.

Pasal 1 angka 21 KUHAP.

Barda Nawawi Arief, 2008, Loc.cit.
} 
Undang Nomor 7 Tahun 2011, Undang-Undang Nomor 23 Tahun 2011, dan Undang-Undang Nomor 8 Tahun 2012. Kedua, penetapan tindak pidana sebagai kejahatan dan pelanggaran dalam undang-undang pidana khusus memiliki implikasi yuridis materiil maupun yuridis formal. Penetapan kualifikasi yuridis tindak pidana sebagai kejahatan dan pelanggaran ini diperlukan untuk "menjembatani" berlakunya aturan umum KUHP dan KUHAP terhadap hal-hal yang tidak diatur dalam undangundang pidana khusus. Implikasi yuridis materiil dari penetapan tindak pidana sebagai kejahatan dan pelanggaran dalam undang-undang pidana khusus, baik yang bersifat intra aturan pidana maupun ekstra aturan pidana, berkaitan dengan masalah "asas nasional aktif", "percobaan tindak pidana", "pembantuan tindak pidana", "perbarengan tindak pidana", "daluwarsa penuntutan", dan "daluwarsa pelaksanaan pidana". Implikasi yuridis formal dari penetapan tindak pidana sebagai kejahatan dan pelanggaran dalam dalam undang-undang pidana khusus berkaitan dengan masalah penangkapan dan penahanan sebagaimana diatur dalam KUHAP.

\section{DAFTAR PUSTAKA}

\section{A. Buku}

Ancel, Marc, 1965, Social Defence: A Modern Approach to Criminal Problems, Routledge \& Paul Kegan, London.

Arief, Barda Nawawi, 1998, Beberapa Aspek Kebijakan Penegakan dan Pengembangan Hukum Pidana, Citra Aditya Bakti, Bandung. , 2007, Masalah Penegakan Hukum dan Kebijakan Hukum Pidana dalam Penanggulangan Kejahatan, Kencana, Jakarta.

, 2008, Bunga Rampai Kebijakan Hukum

Pidana: Perkembangan Penyusunan Konsep KUHP Baru, Kencana, Jakarta. , 2010, Kebijakan Legislatif dalam Penanggulangan Kejahatan Dengan Pidana Penjara, Genta Publishing, Yogyakarta.

Hiariej, Eddy O.S., 2014, Prinsip-Prinsip Hukum

Pidana, Penerbit Cahaya Atma Pustaka, Yogyakarta.

Marzuki, Peter Mahmud, 2009, Penelitian Hukum, Kencana Prenada Media Group, Jakarta.

Moeljatno, 1985, Delik-Delik Percobaan, Delik-
Delik Penyertaan, Bina Aksara, Jakarta.

Sakidjo, Aruan dan Bambang Poernomo, 1990, Hukum Pidana: Dasar Aturan Umum Hukum Pidana Kodifikasi, Ghalia Indonesia, Jakarta.

Soekanto, Soerjono, 2007, Pengantar Penelitian Hukum, UI-Press, Jakarta.

Soekanto, Soerjono dan Sri Mamudji, 2001, Penelitian Hukum Normatif Suatu Tinjauan Singkat, Rajawali Press, Jakarta.

Soemitro, Ronny Hanitijo, 1994, Metodologi Penelitian Hukum dan Jurimetri, Ghalia Indonesia, Jakarta.

Sudarto, 1990, Hukum Pidana I, Yayasan Sudarto, Semarang. ,2006, Kapita Selekta Hukum Pidana, Alumni, Bandung.

\section{B. Makalah}

Adji, Indriyanto Seno, 2014, “Administrative Penal Law: Kearah Konstruksi Pidana Limitatif', Makalah, Pelatihan Hukum Pidana dan Kriminologi, Yogyakarta, 23-27 Februari 2014. 